Jurnal Pengabdian Masyarakat

\title{
Pelatihanan Peningkatan Inovasi Produk UKM \\ Di Desa Jatigedong
}

\author{
Chusnul Rofiah
}

STIE PGRI Dewantara Jombang

e-mail koresponden: chusnulstiepgridewantara@gmail.com

\begin{abstract}
ABSTRAK
Wabah covid 19, telah melumpuhkan perekonomian dunia, khususnya di Indonesia, dampak terbesar yang dirasakan adalah menurunya daya beli masyarakat, karena tergangunya roda perekonomian, dengan penurunan tersebut tentu saja konsumen akan lebih selektif dalam memilih produk yang akan dibeli, inovasi merupakan kunci dari keberhasilan suatu bisnis. Inovasi tidak hanya berkutat pada pengembangan produk namun, pengenalan produk, membuat konsep ulang mengenai produk dalam rangka meningkatan nilai dari suatu produk atau jasa dapat disebut sebagai inovasi. Pelaksanaan selama tiga hari di desa Jatigedong telah sukes dilaksanakan, meningkatknya kemampuan dalam membuat aneka kue, khususny kue modern, peningkatan kemampuan dalam pemasaran serta inovasi serta bertambahnya wawasan mengenai kewirausahaan di harapkan dapat menjadi modal untuk meningkatkan kesejahteraan masyarakat sekitar
\end{abstract}

Kata kunci : Inovasi, Kue Modern, Kesejahteraan

\begin{abstract}
The covid-19 outbreak has crippled the world economy, especially in Indonesia, the biggest impact is the decline in people's purchasing power, because of the economic wheels, with the decline of course consumers will be more selective in choosing which products to buy, innovation is the key to the success of a business. Innovation not only focuses on product development but, product recognition, re-concept of the product in order to increase the value of a product or service can be referred to as innovation. The three-day implementation in Jatigedong village has been implemented, increasing the ability to make various cakes, especially modern cakes, improved capabilities in marketing and innovation as well as increasing insight into entrepreneurship in hopes of becoming capital to improve the welfare of the surrounding community.
\end{abstract}

Keywords : Innovation, Modern Cakes, Welfare 


\section{PENDAHULUAN}

Wabah covid 19, telah melumpuhkan perekonomian dunia, khususnya di Indonesia, dampak terbesar yang dirasakan adalah menurunya daya beli masyarakat, karena tergangunya roda perekonomian, dengan penurunan tersebut tentu saja konsumen akan lebih selektif dalam memilih produk yang akan dibeli, inovasi merupakan kunci dari keberhasilan suatu bisnis (Garis et al., 2019) industri makanan dan minuman merupakan industri yang sangat menjanjikan dan sarat akan inovasi, bukti bahwa industri tersebut menjanjikan dapat dilihat pada pertumbuhan industri makanan dan minuman pada tahun 2017 secara keseluruhan di Indonesia memberikan sumbangan yang tidak bisa dibilang kecil, yaitu Rp. 540 triliun dengan nilai yang lebih tinggi dari industri yang lain (Kojo et al., 2019).

Namun sangat disayangkan sekali kebanyakan UKM yang bergerak di bidang makanan dan minuma jarang sekali menerapkan inovasi berkelanjutan terhadap produk makanan dan minuman mereka (Kojo et al., 2019) hal tersebut terjadi pada kelompok usaha makanan di desa Jatigedong, fokus produk mereka adalah makanan kue basah tradisional, sebelum wabah covid, para ibu-ibu tersebut banyak menerima pesanan dari acara besar di desa seperti hajatan pernikahan, pertemuan rutin kelompok PKK, arisan dan lain sebagainya, namun setelah adanya wabah covid serta dengan adanya protokol kesehatan yang membatasi jarak atau phsyical distancing menyebabkan omset penjualan menurun secara drastis, kelemahan dari ue tradisional khusunya kue basah adalah daya tahan produk yang singkat, sehingga kalau tidak segera terjual akan menyebakan kerusakan pada produk tersebut,

Dengan segala permasalahan tersebut maka pada tujuan diadakan program pengabdian ini adalah sebagai berikut : (1) membuka wawasan dari para peserta mengenai pentingnya suatu inovasi dari proses pencarian ide sampai implementasi dari ide tersebut, (2) memberikan praktek nyata produk makanan dan minuman yang memiliki nilai inovsi dan (3) evaluasi dari hasil program pengabdian masyarakat tersebut.

\section{Inovasi Produk}

Inovasi tidak hanya berkutat pada pengembangan produk namun, pengenalan produk, membuat konsep ulang mengenai produk dalam rangka meningkatan nilai dari suatu produk atau jasa dapat disebut sebagai inovasi (Dhewanto et al., 2015) dengan adanya inovasi produk tersebut dapat berdampak pada meningkatknya spesifikasi dari produk serta kualitas produk tersebut, menurut Dealtry dan Rademakers, (2005) secara spesifik inovasi dapat dibagai sebagari berikut :

a. Inovasi berupa layanan, produk atau kombinasi dari keduanya

b. Inovasi dapat berupa metode baru dalam kegiatan yang mampu meningkatan atau memiliki nilai tambah berupa efisiensi biaya atau menghasilkan produk yang lebih baik dari yang lama atau dari pesaing 
Jurnal Pengabdian Masyarakat

c. Inovasi berupa suatu metode baru yang digunakan dalam mengelola, mengkoordinasi dan mengawasi kegiatan, dan tanggung jawab karyawan

d. Inovasi dapat berupa kombinasi dari keseluruhan proses, sistem organisasi ataupun perpaduan dari produk

Terdapat perbedaan yang mendasar antara inovasi produk dan inovasi proses produk, inovasi suatu produk melibatkan menggunakan aplikasi pengetahuan untuk melakukan pengembangan produk yang baru dengan peralatan yang baru, sedangkan pada inovasi proes produk melibatkan suatu pengembangan praktik dan manajemen dalam suatu organisasi yang baru, keunggulan dari inovasi produk tidak hanya berlaku pada produk berupa barang tetapi juga bisa dilakukan pada pelayanan jasa atau kombinasi dari keduanya (Anggraini et al., 2014)

\section{Keunggulan Kompetitif}

Keunggulan kompetitif tumbuh dari nilai kegunaan yang dibentuk oleh perusahaan kepada kosumen, pelanggan memandang dari harga yang ditawarkan dari suatu produk yang memiliki manfaat lebih dari yang mereka harapkan (Anggraini et al., 2014)

\section{METODE PELAKSANAAN}

Metode yang digunakan dalam pengabdian masyarakat, dengan dua metode yaitu presentasi dan praktek adapun alokasi dari metode tersebut adalah sebagai berikut :

a. Presentasi, presentasi di lakukan di hari pertama, adapun materi yang dibahasa adalah mengenai definisi dan motivasi dari wirausaha, pemasaran produk yaitu kue modern

b. Praktek, adapun praktek dilakukan di hari kedua, adapun praktek yang dilakukan adalah membuat kue modern

c. Presentasi di hari ketiga, presentasi dari hasil kegiatan dari tiap kelompok, untuk mengutarakan kesulitan dan permasalahan yang mereka hadapi.

\section{HASIL DAN PEMBAHASAN}

Hari pertama adalah proses pemberian materi dalam bentuk presentasi narasumber yaitu ibu Chusnul Rofiah, SE, MM memberikan materi berkenaan dengan pentingnya untuk berwirausaha, wirausaha bukanlah suatu yang hanya dipelajari melalui teori namun harus beserta dengan praktek, dengan adanya wirausaha maka akan meningkatkan perekonomian, khususnya di Indonesia, namun sayangnya banyak yang berpendapat bahwa wirausaha hanyalah untuk orang-orang yang tidak diterima di dunia kerja, sehingga sebagai orang tua jarang sekali yang menginginkan putra- putrinya setelah kuliah melanjutkan untuk berwirausaha, definisi kerja bagi mereka adalah bekerja di perusahaan bukan wirausaha, oleh karena itu di awal pertemuan di singgung mengenai mengubah paradigma dan memperlihatkan potensi untuk jadi wirausaha, dengan terbukanya wawasan diharapkan peserta dapat membuka mental block di dalam 
Jurnal Pengabdian Masyarakat

diri sendiri, bahwa wirausaha sulit dan malu apabila di suruh berjualan harus dihilangkan.

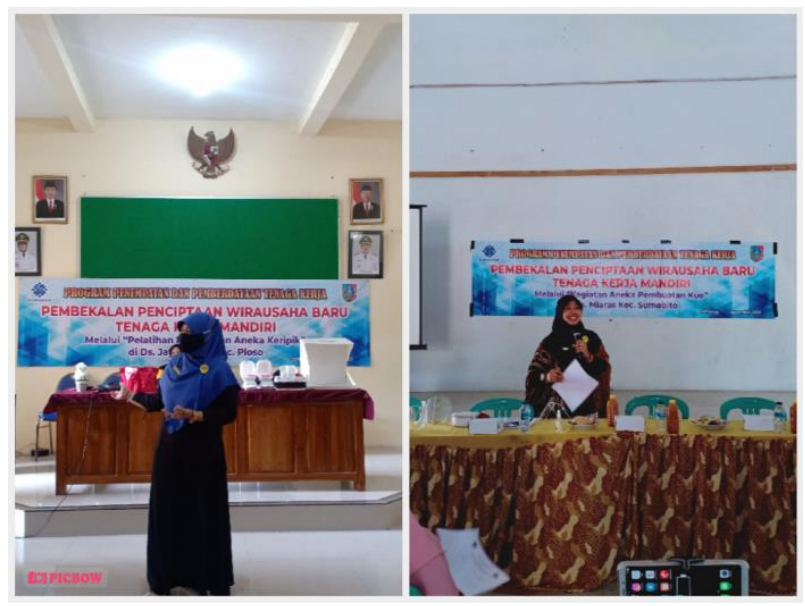

Gambar 1. Sesi presentasi

Hari kedua adalah tahap pelaksanaan praktek, di hari kedua ini para peserta diajari untuk membuat aneka kue modern, adapun kue yang di buat adalah kue bolu, red velvet dan korean garlic bread. Kenapa praktek kue tersebut dipilih karena kue tersebut termasuk kue yang memiliki daya tahan yang lebih lama daripada kue tradisional serta di Jombang sendiri pemint akan kue tersebut tergolong tinggi, inovasi yang diberikan adalah dengan mengubah bentuk dari kue basah tradisional di rubah menjadi kue modern yang tahan lama.

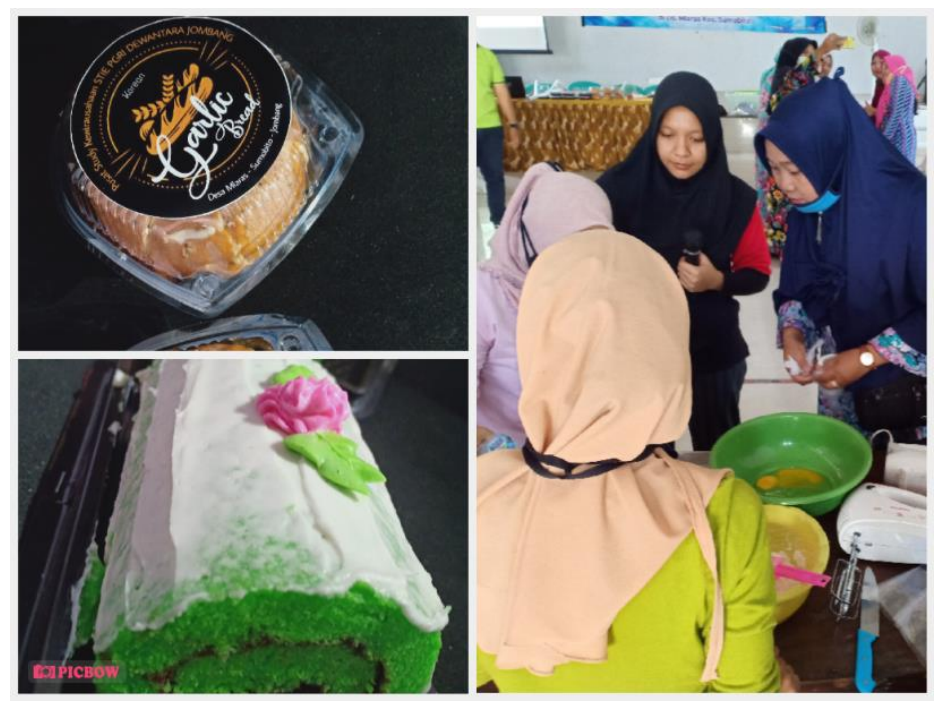

Gambar 2 proses pembuatan kue

Proses pembuatan kue berjalan dengan lancar dan antusias, setelah selesai membuat kue maka peserta di wajibkan untuk menjual hasil praktek kepada masyarakat sekitar dan upload pada media sosial. 
Jurnal Pengabdian Masyarakat

Pertemuan ketiga atau terakhir adalah sesi pertanggungjawaban dari tiap kelompok untuk melaporkan hasil jualan, serta permasalahan yang dihadapi ketika berjualan, serta sesi tanya jawab dengan narasumber mengenai solusi yang dihadapi, adapun permasalahan yang timbul adalah sebagai berikut :

1. Waktu yang diberikan sangat singkat hanya satu hari sehingga peserta kurang maksimal dalam memasarkan produknya

2. Produk yang dijual kurang familiar di telinga masyarakat sekitar sehingga perlu upaya ekstra untuk mengenalkan produk tersebut.

3. Kurang maksimal peserta dalam menggunakan media sosial untuk menarik konsumen, karena banyak sekali dari par peserta yang tidak memiliki media sosial seperti facebook dan instagram

\section{SIMPULAN}

Pelaksanaan selama tiga hari di desa Jatigedong telah sukes dilaksanakan, meningkatknya kemampuan dalam membuat aneka kue, khususny kue modern, peningkatan kemampuan dalam pemasaran serta inovasi serta bertambahnya wawasan mengenai kewirausahaan di harapkan dapat menjadi modal untuk meningkatkan kesejahteraan masyarakat sekitar, peserta pelatihan memanfaatkan media sosial yaitu whtasaap untuk tetap berhubungan dengan pihak STIE PGRI Dewantara, dengan media tersebut diharapkan program tetap berjalan waluapun pelatihan telah usai.

\section{DAFTAR PUSTAKA}

Anggraini, N., Marnis, M., \& Samsir, S. (2014). Strategi orientasi pasar, inovasi, dan orientasi pembelajaran pengaruhnya terhadap kinerja usaha serta dampaknya terhadap keunggulan bersaing (Studi pada industri jasa salon kecantikan dan spa di kota pekanbaru). Jurnal Sosial Ekonomi Pembangunan, 4(12), 195-310.

Dealtry, R., \& Rademakers, M. (2005). Corporate universities: driving force of knowledge innovation. Journal of Workplace Learning.

Dhewanto, W., Indradewa, R., Ulfa, W. N., Rahmawati, S., Yoshanti, G., \& Lumanga, C. Z. (2015). Manajemen Inovasi untuk Usaha kecil dan mikro. Bandung: $C V$ Alfabeta.

Garis, R. R., Garvera, R. R., \& Sari, P. (2019). Pemberdayaan Masyarakat Prasejahtera Melalui Inovasi Keripik Pisang Rumput Laut Di Desa Pajaten Kecamatan Sidamulih. Abdimas Galuh, 1(1), 83-93.

Kojo, C., Rogi, M. H., \& Lintong, D. C. (2019). Pkm Pengembangan Inovasi Produk Makanan Dan Minuman Yang Dijual Di Seputaran Kampus Unsrat Bahu. Jurnal LPPM Bidang EKOSOSBUDKUM, 4(2), 68-76. 